Jurnal Media Komunikasi Pendidikan Pancasila dan Kewarganegaraan

Volume 2, Nomor 1 April 2020

\title{
KELEMAHAN INFORMASI SYARAT KONTRAK DALAM PERDAGANGAN SECARA ELEKTRONIK BERAKIBAT KEADILAN BELUM BERPIHAK PADA KONSUMEN
}

\author{
Nurlaeli Sukesti Ariani Nasution \\ Faculty of Law, Universitas Wijayakusuma, Purwokerto - Indonesia
}

\begin{abstract}
This study intends to analyze the terms of contract conditions in electronic of B2C type and its main focus is on the weakness of contract conditions information as a signal of justice not in favor of the consumer's position between business actors and consumers. Therefore, the research conducted is a type of normative juridical legal research by deductive thinking from a general nature to a specific nature. The study explained that the information on contract terms, contract terms themselves, and contracts agreed by the parties in electronic transactions or trade place more emphasis on electronic procedure steps rather than substantive understanding of the parties. Article 9 of the ITE Law and Article 7 letter b of the Consumer Protection Act only explain "complete and correct information". Whereas the weight of justice is not only on sharing information, but the substance of the information being informed, such as the terms of the contract and the contract itself. That is, justice has not sided with consumers in B2C electronic commerce. That explains the weaknesses in contract conditions information in various aspects.
\end{abstract}

Keywords: Information, contract terms, fair, consumers.

\begin{abstract}
Abstrak
Penelitian ini bermaksud menganalisis mengenai informasi syarat kontrak dalam perdagangan secara elektronik jenis $\mathrm{B} 2 \mathrm{C}$ dan fokus utamanya padakelemahan informasi syarat kontrak sebagai sinyal keadilan belum berpihak pada konsumen posisi antara pelaku usaha dan konsumen. Oleh Karena itu, penelitian yang dilakukan merupakan jenis penelitian hukum yuridis normatif dengan cara berfikir deduktif dari hal yang sifatnya umum kepada hal yang sifatnya khusus. Penelitian menjelaskan bahwa informasi syarat kontrak, syarat kontrak itu sendiri, maupun kontrak yang disepakati oleh para pihak dalam transaksi atau perdagangan secara elektronik lebih menekankan pada langkah-langkah prosedur secara elektronik dibanding pemahaman para pihak secara substantif. Pasal 9 UU ITE dan Pasal 7 huruf b UU Perlindungan Konsumen hanya menjelaskan mengenai "informasi yang lengkap dan benar". Padahal bobot keadilan bukan hanya pada membagi informasinya, namun substansi dari ihwal yang diinformasikan itu, seperti syarat kontrak dan kontrak itu sendiri. Artinya, keadilan belum berpihak pada konsumen dalam perdagangan secara elektronik B2C. Hal itu menjelaskan adanya kelemahan informasi syarat kontrak dalam berbagai aspek.
\end{abstract}

Kata Kunci: Informasi, syarat kontrak, adil,konsumen

\section{Pendahuluan}

Penelitian ini dilakukan

berhubungan dengan transaksi perdagangan melalui dunia internet dan perlindungan konsumen (consumer protection) dalam konteks hukum Nasional (tata hukum Indonesia). Transaksi perdagangan melalui internet 
dalam hubungannya dengan perlindungan konsumen penting untuk diteliti karena beberapa alasan. Pengaturan perdagangan melalui internet masih memunculkan banyak pertanyaan konseptual atau Teoretis yang menandai kebutuhan untuk membangun penjelasan-penjelasan konseptual dan teoretis yang lebih detail sampai kebutuhan peraturan perundangundangan yang lebih kompeks untuk mampu melindungi konsumen secara baik. Aktivitas bisnis melalui internet atau yang lazim disebut transaksi bisnis atau perdagangan elektronik (electronic commerce disingkat E-Commerce, disebut juga cyber-commerce atau disingkat c-commerce), telah menjadi kecenderungan global atau internasional. Indonesia tentu tidak dapat mengisolasi diri dari penggunaan internet oleh bangsa Indonesia dan menutup akses perdagangan elektronik itu. Perusahaan terkemuka pun mulai dari toko buku (book store) besar di Amerika sampai penjualan mobil mewah telah turut menawarkan produk-produknya, baik barang maupun jasa menggunakan jaringan internet dan dapat diakses oleh bangsa Indonesia untuk memenuhi kebutuhannya.

Perdangan berbasis jaringan ruang tidak terbatas dan dapat diakses oleh semua orang dalam transaksi elektronik tersebut potensial memunculkan penyalahgunaan oleh pihak-pihak yang terlibat di dalamnya Penyalahgunaan dalam perdagangan elektronik ini lebih kompleks dibanding perdagangan konvensional. Muncul berbagai penyalahgunaan, seperti penipuan melalui iklan (deceptive advertisements) atas barang-barang yang diperdagangkan sampai tidak adanya tanggung jawab yang menjamin barang sampai di tangan pembeli, dan berbagai praktik perdagangan lain tidak jujur (unfair trading practices). Praktikpraktik tidak jujur ini menandai kebutuhan perlindungan terhadap konsumen dalam transaksi perdagangan elektronik. Di Indonesia sesungguhnya di samping terdapat Undang-Undang Nomor 8 Tahun 1999 tentang Perlindungan Konsumen (selanjutnya disebut UU PK) juga Undang-Undang Nomor 11 Tahun 2008 tentang Informasi dan Transaksi Elektronik, yang diubah oleh Undang-Undang Nomor 19 Tahun 2016 tentang Perubahan atas UndangUndang Nomor 11 Tahun 2016 tentang Informasi dan Transaksi Elektronik (selanjutnya disebut UU ITE. Di samping itu, UU PK hanya mengatur sebatas hubungan antara pelaku usaha dan konsumen. Dalam perdagangan elektronik, hubungan pelaku usaha dan konsumen dapat diperantarai oleh pihak ketiga yang justru menentukan hubungan antara pelaku usaha dan konsumen dapat berlangsung atau tidak, bukan pelaku usaha dan konsumen itu sendiri yang menentukan. Hal-hal itu bergantung pada pemenuhan syarat kontrak (terms of contract), baik oleh pelaku usaha maupun konsumen.

Salah satu aspek penting dalam perdagangan secara elektronik yang dapat menjadi indikator perlindungan konsumen dan kejujuran pelaku usaha adalah kontrak elektronik. Kontrak elektronik diartikan sebagai perjanjian para pihak yang dibuat melalui Sistem Elektronik. ${ }^{1}$ Arti penting kontrak elektronik bagi perdagangan secara elektronik tampak dari ketentuan UU ITE yang menegaskan bahwa "Pelaku usaha yang menawarkan produk melalui Sistem Elektronik harus menyediakan informasi yang lengkap dan benar berkaitan dengan syarat kontrak, produsen, dan produk yang 
ditawarkan."2 Ketentuan tersebut mengatur mengenai syarat kontrak yang lengkap dan benar. Permasalahan muncul tentu berkaitan dengan standar informasi yang lengkap dan benar mengenai syarat kontrak (terms of contract). Penjelasan Pasal 9 UU ITE menentukan bahwa :

Yang dimaksud dengan "informasi yang lengkap dan benar" meliputi :

a. informasi yang memuat identitas serta status subjek hukum dan kompetensinya, baik sebagai produsen, pemasok, penyelenggara maupun perantara;

b. informasi lain yang menjelaskan hal tertentu yang menjadi syarat sahnya perjanjian serta menjelaskan barang dan/atau jasa yang ditawarkan, seperti nama, alamat, dan deskripsi barang/jasa.

Pasal tersebut sejalan dengan ketentuan Pasal 7 huruf $b \quad$ UU Perlindungan Konsumen yang menentukan bahwa "kewajiban pelaku usaha memberikan informasi yang benar, jelas, dan jujur mengenai kondisi dan jaminan barang dan/atau jasa serta memberi penjelasan penggunaan, perbaikan, dan pemeliharaan."

Permasalahan syarat kontrak sebenarnya lebih dari sekadar informasi yang lengkap dan benar, namun keseimbangan antara pelaku usaha dan konsumen.

Ketentuan Pasal 9 UU ITE maupun Pasal 7 huruf b UU PK membutuhkan konsekuensi hukum apabila tidak dipatuhi oleh pelaku usaha, sehingga kerugian konsumen dapat dicegah atau diganti. Hal itu tidak diatur dalam UU ITE, kecuali upaya prevensi dengan adanya "sertifikasi keandalan" yang akan diberikan oleh Lembaga Sertifikasi Keandalan ${ }^{3}$. Dalam Pasal 9 UU ITE.
Penjelasan Pasal 10 UU ITE menerangkan sertifikat keandalan.

Berdasarkan beberapa kasus penipuan dalam situs jual beli secara elektronik tidak pandang siapa korban, maka urgen untuk diteliti variasi syarat kontrak yang dipergunakan oleh para pelaku usaha dalam perdagangan secara elektronik berdasarkan kategori sebagaimana diatur Pasal 9 UU ITE maupun Pasal 7 huruf $b$ UU PK serta bobot keadilan. Variasi syarat kontrak maupun kontrak elektronik menjelaskan polanya dalam perdagangan secara elektronik, baik terhadap usaha (bisnis) secara ekektronik yang telah maupun belum memeroleh sertifikasi keandalan.

Dari uraian yang dangkal tersebut di atas maka penulis memberi judul disertasi "Kelemahan informasi syarat kontrak dalam perdagangan secara elektronik berakibat keadlian belum berpihak pada konsumen".

\section{Rumusan Masalah}

Dari latar belakang diatas, maka dapat ditarik perumusan masalah sebagai berikut : "Apa saja kelemahankelemahan yang berkaitan dengan informasi syarat kontrak dalam perdagangan secara elektronik berakibat keadilan belum berpihak pada konsumen?".

\section{Metodologi Penelitian}

1. Penelitian ini bersifat yuridis normatif, yaitu hukum dipandang suatu sistem atau kaedah normatif yang bersifat otonom atau mandiri terlepas dari faktor-faktor non hukum dalam hal ini undangundang informasi dan tehnologi dan undang-undang perlindungan konsumen.

2. Jenis penelitian yaitu clinical legal research yaitu menemukan hukum

,Pasal 10 UU ITE. 
ini abstracto dalam perkara in concretonya. In abstrakto adalah aturan yang sifatnya umum yaitu undang-undang perlindungan konsumen dan undang-undang informasi dan tehnologi dan in concretonya yaitu informasi syarat kontrak dalam perdaganan secara elektronik.

3. Metode pengumpulan data : Data sekunder diperoleh melalui investarisasi terhadap peraturan perundang-undangan, literatur dan dokumen resmi kemudian dicatat menurut relevansinya dengan masalah yang diteliti. Sebagai data penunjang dari data primer yang berupa wawancara dengan pihak terkait.

4. Metode Analisa data : Data yang diperoleh kemudian dianalisa secara kualitatif dengan cara berfikir deduktif dengan menggunakan silogisme yaitu sebagai premis mayor adalah peraturan perundangundangan yang mengatur mengenai informasi syarat kontrak dalam perdagangan secara elektronik (UU ITE dan UU Perlindungan Konsumen), sedangkan hasil penelitian dipakai sebagai premis minor, selanjutnya antara premis mayor dan premis minor dihubungkan melalui pembahasan untuk kemudian ditarik kesimpulan.

\section{Hasil Dan Pembahasan}

\section{A. Kondisi yang Menstimulasi Informasi Syarat Kontrak Bersifat Melindungi atau Merugikan Konsumen}

Perdagangan secara elektronik merupakan bentuk hubungan timbal balik yang bersifat transaksional antara pelaku usaha dan pelaku usaha (B2B) atau pelaku usaha dan konsumen (B2C), baik dalam konteks pemenuhan kebutuhan barang atau jasa, yang dilakukan melalui media internet atau dunia maya (virtual world). Seperti halnya hubungan perdagangan dalam dunia nyata (real world), perdagangan secara elektronik atau perdagangan dalam dunia maya ini juga tidak steril dari perilaku yang potensial merugikan salah satu atau beberapa pihak yang saling mengadakan transaksi. Bahkan media internet lebih mudah menjadi sarana untuk melakukan kejahatan atau setidak-tidaknya merugikan konsumen dalam perdagangan secara elektronik, terutama ketika konsumen merupakan pihak yang tidak paham betul mengenai dunia virtual dan sifat-sifat perdagangan yang ada di dalamnya. Hal ini terutama terjadi dalam perdagangan secara elektronik yang toko online-nya hanya fasilitasi iklan, dan antara penjual dan pembeli berhubungan di luar toko online itu, seperti toko online OLX, meskipun toko online tersebut telah mengingatkan pembeli untuk mengambil langkahlangkah jual-beli dengan aman. Perdagangan dalam model toko online seperti ini sesungguhnya bukan perdagangan secara elektronik karena toko online hanya membantu mengiklankan.

OLX sebagai misal, memiliki artikel tentang "Tips Jual dan Beli Aman di OLX", yaitu untuk "Tips Berbelanja Aman" antara lain:

1. Usahakan membeli produk dengan menggunakan metode Ada Barang Ada Uang/Ketemuan/Cash On Delivery (COD), cara lain (seperti transfer, DP, dll) tidak disarankan;

2. Pastikan untuk mengecek barang terlebih dahulu. Jika penjual atau produk berada di luar kota, mintalah bantuan kepada keluarga atau teman yang tinggal di kota tersebut untuk mengecek produk yang akan dibeli;

Di samping itu, ada "Tips Berjualan Aman", antara lain : 
1. Berikan informasi yang detail pada iklan anda, agar calon pembeli memiliki persepsi yang sama terhadap produki yang anda tawarkan;

2. Usahakan untuk bertransaksi dengan metode Ada Barang Ada Uang/Ketemuan/Cash On Delivery (COD), dan pastikan pembeli telah memeriksa kondisi barang tersebut agar tidak terjadi komplain setelahnya.

Tentu saja Tips tersebut dapat diskip oleh calon pembeli atau penjual waktu mendaftar di toko online OLX, sehingga sering pembeli dan penjual bersepakat dalam kondisi yang berisiko. Artinya, praktik perdagangan secara elektronik yang tidak aman ditempuh oleh para pihak, khususnya konsumen dalam perdagangan $\mathrm{B} 2 \mathrm{C}$.

Berdasarkan hal tersebut, informasi syarat dan ketentuan kontrak merupakan hal penting, bahkan esensial. Secara umum, fungsi "syarat dan ketentuan" (terms and contions) di samping menjadi pedoman bertransaksi, juga dapat membantu penyelesaian permasalahan yang muncul dalam perdagangan secara elektronik. Informasi syarat kontrak merupakan informasi atas "syarat dan ketentuan" yang membatasi hak-hak dan tanggung jawab para pihak dalam kontrak, sehingga kedua belah pihak yang bertransaksi mengetahui hal-hal harus dilakukan dalam untuk tercapainya kesepakatan di antara mereka. Ketidakterpenuhan hak salah satu atau kedua pihak merupakan bentuk wanprestasi (ingkar janji).

Dalam hal ini berlaku prinsipThe Privity of Contract, yaitu pelaku usaha memiliki kewajiban untuk melindungi konsumen, dengan informasi syarat kontrak yang jelas, jujur, serta ditulis

4 Faye Fangfei Wang, Law of Electronic Commercial Transactions Contrmporary dalam bahasa yang dapat dimengerti. Hal ini menuntut peraturan perundangundangan yang mengatur perdagangan secara elektronik mensyaratkan infrormasi syarat kontrak yang menjadikan konsumen tidak dirugikan dan jual-beli berlangsung secara jujur (fair).

Informasi "syarat dan ketentuan" itu sendiri merefleksikan informasi mengenai persetujuan atas syarat dan ketentuan yang hendak dinegosiasikan oleh kedua pihak. Informasi syarat dan ketentuan yang sangat sedikit atau minim tentu setidak-tidaknya meningkatkan risiko kesalahpahaman, perselisihan dagang yang dapat menimbulkan pembayaran atau penundaan kinerja, kompensasi, dan sengketa jaminan. ${ }^{4}$

Berdasarkan hal tersebut, membaca informasi syarat kontrak merupakan suatu keharusan untuk dapat memahami transaksi yang akan dilakukan beserta konsekuensinya. Tidak dibacanya informasi syarat kontrak seharusnya juga menjadi syarat sahnya kontrak, di luar syarat yang telah ditentukan oleh KUHPerdata. Toko online dapat membuat mekanisme proses penutupan kontrak yang mengharuskan para pihak melalui proses membaca informasi syarat kontrak. Artinya, tanpa proses pembacaan, para pihak tidak dapat meneruskan ke tahap penutupan kontrak. Dalam kenyataannya, semua toko online hanya membuat proses pembacaan informasi syarat kontrak sekali untuk selamanya ketika para pihak "submit" (masuk) pada toko online pada pertama kali. Realitas ini yang memberi jalan sikap ketidakhati-hatian kosumen dalam memutuskan untuk bertransaksi atau tidak bertransaksi.

Issues in The EU, US and China, London and New York: Routledge, 2014. Hal. 66. 
Informasi syarat kontrak tidak
hanya menentukan keamanan perdagangan secara elektronik, yang tidak hanya ditujukan bagi salah satu pihak, namun juga keamanan bagi kedua pihak yang bertransaksi tersebut. Informasi syarat kontrak berbeda-beda antara satu toko online dan toko online lainnya. Hal ini disebabkan tidak ada ketentuan dalam hukum Nasional mengenai syarat kontrak. Informasi syarat kontrak merupakan salah satu ruang yang lazim dipergunakan oleh para pelaku bisnis (business operators) untuk mengambil posisi yang lebih menguntungkan atau menentukan ketika bertransaksi dengan konsumen (B2C). Meskipun demikian, toko-toko online besar umumnya memberikan syarat kontrak yang lebih detail dan rigid, bukan hanya soal transaksinya itu sendiri, namun juga informasi pribadi konsumen, seperti informasi dalam hubungan dengan kartu kredit atau kartu ATM atau alat bayar lainnya yang dimungkinkan.

Lebih dari itu ada informasi untuk bantuan bagi konsumen, seperti di amazon.com terdapat menu "Help". Menu tersebut berisi berbagai informasi mengenai langkah-langkah yang niscaya ditempuh untuk hal-hal tertentu, di antaranya : cancel items or orders, manage your order, return items your ordered, track your package, change your payment method, manage your accour information, about two-step verification. ${ }^{6}$

Informasi syarat kontrak ini menjadi pintu masuk bagi konsumen untuk melanjutkan keinginannya dalam memenuhi kebutuhan atas barang atau jasa. Dengan informasi tersebut, setidaktidaknya konsumen dapat mengetahui perlindungan atas posisinya sebagai faktor kalkulasi untuk bertransaksi atau tidak. Apabila informasi syarat kontrak menunjukkan posisi lemah atau tidak adil pada konsumen, secara rasional konsumen seharusnya tidak mengambil risiko untuk melakukan transaksi online tersebut, demikian pula sebaliknya. Hal ini berarti antara kelemahan informasi syarat kontrak yang mengakibatkan ketidakseimbangan posisi antara pelaku bisnis dan konsumen ataupun ketidakamanan bagi konsumen, tidak berbanding lurus dengan sikap konsumen untuk memilih tetap bertransaksi atau membatalkan transaksi dengan meninggalkan toko online dan mencari toko online lain yang dianggap lebih adil dan melindungi kepentingan konsumen apabila terjadi wanprestasi atau perbuatan melawan hukum.

Sebelum menguraikan kelemahan informasi syarat kontrak dalam transaksi secara elektronik, dikemukakan terlebih dahulu hal-hal yang berhubungan atau kondisi yang menstimulasi informasi syarat kontrak sebagai aspek yang melindungi kepentingan atau sebaliknya merugikan para pihak atau salah satu pihak.

\section{Jarak Jauh (Great Distances)} antara Pengusaha dan Konsumen

Salah satu karakteristik dari perdagangan secara elektronik di dunia maya (virtual world), yaitu antara pengusaha dan konsumen (B2C) sering berada dalam jarak yang sangat jauh dalam dunia nyata (real world). Banyak di antara pengusaha dan konsumen yang melakukan perdagangan secara elektronik itu berada di negara yang berbeda, seperti amazon.com dan aliexpress bagi konsumen dari Indonesia, di samping beberapa memiliki kantor operasional di Indonesia. Meskipun perdagangan secara elektronik mereduksi jarak konseptual antara pengiklanan dan penutupan kontrak, yang berarti mempermudah mewujudkan hubungan toko online atau penjual (pelaku usaha) dan konsumen. Pada saat yang sama, 
perdagangan secara elektronik menyediakan ruang yang lebih mudah menimbulkan masalah, bahkan lebih rumit, khususnya bagi konsumen atas prestasi penjual atau pelaku usaha, termasuk upaya hukum apabila terjadi ingkar janji (wanprestasi) ataupun perbuatan melawan hukum.

Fakta jarak yang jauh ini menciptakan risiko dan ketidakpastian yang lebih besar bagi konsumen ketika terjadi wanprestasi atas kontrak yang telah mereka sepakati (breaches of the contracts) dibandingkan dengan transaksi secara tradisional yang berhadap-hadapan antara konsumen dan pengusaha dalam yurisdiksi yang sama. ${ }^{5}$ Dalam transaksi atau jual-beli secara tradisional, keputusan untuk melanjutkan jual-beli atau meninggalkannya lebih sederhana bagi para pihak. Jarak yang jauh dalam perdagangan secara elektronik itu pula yang memengaruhi kalkulasi para pihak, khususnya konsumen untuk melakukan upaya-upaya hukum, lebih-lebih berbeda negara antara pengusaha dan konsumen. Meskipun demikian, banyak konsumen yang mengabaikan jarak jauh antara pengusaha dan konsumen. Para konsumen mengabaikan jarak jauh itu sebagai halangan untuk bertransaksi secara elektronik. Semua responden (20 orang konsumen yang pernah melakukan transaksi online) yang peneliti wawancarai, 100 persen menunjukkan hal itu. Artinya, konsumen Indonesia mengabaikan jarak jauh dengan penjual dalam perdagangan secara elektronik. Hal ini di antaranya karena pengalaman yang menunjukkan tidak ada permasalahan secara pribadi maupun berdasarkan pengalaman atas keberhasilan orang lain yang dikenal,

5 Sutatip Yuthayotin, 2015, Access to Justice in Transnational B2C E-Commerce, A Multidimentional Analysis of Consumer meskipun hal tersebut sesungguhnya sama sekali tidak menjadi jaminan.

Kondisi jarak yang jauh antara toko online atau pelaku usaha dan konsumen ini merupakan persoalan yang sulit untuk diatur oleh salah satu negara tanpa adanya kerja sama (kooperasi) dengan negara lain. Hal tersebut terutama berkaitan dengan penyelesaian sengketa atau perkara apabila terjadi perbuatan melawan hukum.

Demikian pula ketika terjadi komplain, sehingga barang harus dikirim balik oleh konsumen dan toko online harus mengirim ulang (reshiping). Tentu jarak yang jauh menimbulkan biaya yang lebih mahal, sehingga menjadi tidak efisien bagi konsumen maupun toko online atau pelaku usaha (penjual). Kondisi tersebut kadang-kadang melahirkan keengganan konsumen untuk mengirim balik dan hanya menyisakan kekecewaan bagi konsumen. Sementara itu, toko online atau penjual yang difasilitasi tidak begitu saja mempertimbangkan klaim konsumen sebagai benar adanya, sehingga tidak ditanggapi oleh pelaku usaha

Kondisi jarak jauh yang bersifat lintas negara ini juga menjadikan konsumen kemungkinan harus tunduk pada hukum perdagangan secara elektronik yang membatasi syarat dan ketentuan beserta informasinya. Demikian pula sebaliknya bagi penjual atas hukum yang berlaku di negara tempat konsumen berada. Di Ingris terdapat "the Consumer Contracts (Information, Cancellation and Additional Charges) Regulations 2013" yang mensyaratkan pedagang untuk memberi informasi tertentu. Ketentuan ini merupakan pengganti dari "Distance Selling Regulations", yang berlaku

Protection Mechanisms, Switzerland: Springer, Hal.1. 
sebelum 13 Juni 2014. Indonesia belum memiliki ketentuan khusus seperti itu, kecuali UU ITE.

Ketentuan tersebut menjadi standar dan pedoman informasi syarat kontrak dalam perdagangan secara elektronik di Inggris sebagai konsekuensi perdagangan jarak jauh. Hal tersebut semata-mata untuk memberikan jaminan perlindungan kepada konsumen dalam perdagangan secara elektronik, yang menjadi kewajiban pedagang online.

\section{Kesadaran dan Kepercayaan Konsumen}

Informasi syarat kontrak sangat berhubungan dengan kesadaran maupun kepercayaan konsumen dalam melakukan transaksi secara elektronik. Secara umum, informasi yang tidak benar dan menimbulkan pengalaman yang merugikan konsumen, maka pada gilirannya akan melahirkan ketidakpercayaan pada toko online, penjual atau pelaku usaha. Oleh karena itu, informasi syarat kontrak tidak hanya mengandung pengertian sebagai pemenuhan kewajiban hukum, namun juga dengan etika bisnis yang menandai baik-buruk perilaku pelaku usaha terhadap konsumennya maupun dalam hubungan dengan lingkungan bisnis itu sendiri, termasuk dengan pelaku usaha lainnya.

Permasalahan utama berhubungan dengan informasi syarat kontrak, yaitu mengenai kesadaran konsumen. Kesadaran dalam hal ini secara umum diartikan dengan keadaan mengerti atau keinsafan atau hal yang dirasakan atau dialami oleh seseorang. ${ }^{6}$ Kesadaran ini

\footnotetext{
6 www.artikata.com, atau https://www.kamusbesar.com/kesadaran, diunduh pada Jumat, 16 April 2020, pukul 09:57 wib.

7 Ibid.

8 Thompson S.HAL. Teo, Jing Liu, 2007, "Consumer trust in e-commerce in the United
}

berbanding lurus dengan kepercayaan konsumen (consumer confidence, consumer trust) maupun risiko konsumen dalam perdagangan secara elektronik. Kepercayaan diartikan sebagai "angapan atau keyakinan bahwa sesuatu yang dipercaya itu benar atau nyata". ${ }^{7}$ Kepercayaan (trust) memainkan peran penting dalam banyak interaksi sosial dan ekonomi yang melibatkan ketidakpastian dan ketergantungan. Semenjak ketidakpastian itu ada dalam transaksi melalui internet, banyak peneliti menyatakan bahwa kepercayaan merupakan faktor kritis yang memengaruhi proliferasi (perkembangan) perdagangan secara elektronik. Konsep kepercayaan itu krusial disebabkan pengaruhnya pada sejumlah faktor esensial pada transaksi online, termasuk keamanan dan privasi. Lebih dari itu, meskipun perdagangan secara elektronik membawa kemanfaatan atau keuntungan, baik pada vendor (penjaja) maupun konsumen, namun juga pembatasan, seperti separasi fisik antara pembeli dan penjual, serta antara pembeli dan barang yang diperdagangkan. Untuk mereduksi rintangan (barriers), penjaja harus membangun hubungan kepercayaan (trustworthy relationship) untuk mempertahankan loyalitas/kesetiaan (customer loyalty) pelanggan. ${ }^{8}$ Kepercayaan pelanggan tentu memengaruhi atau memiliki konsekuensi pada perilaku dan keinginan untuk membeli dan persepsi risiko dalam situasi pembelian. Dari 20 (dua puluh) orang konsumen yang diwawancarai, 18 (delapan belas) orang

\footnotetext{
States, Singapore and China", dalam Omega, The International Journal of Management Science, Hal.22 (22-38), www.elsevier.com/locate/omega atau www.sciencedirect.com, diakses pada tanggal 25 Maret 2020, pukul 10.00 wib.
} 
di antaranya membeli pada toko online tertentu karena sudah percaya, meskipun sebenarnya hanya karena kebiasaan. Sementara 2 (dua) orang lainnya karena ikut-ikutan belaka, sehingga pada dasarnya memiliki kekhawatiran terjadinya kerugian dalam perdagangan secara elektronik yang dilakukannya atau tidak sepenuhnya percaya.

Survai belakangan yang dilakukan di Uni Eropa (EU) mengenai kepercayaan konsumen mengungkapkan bahwa tingkat kepercayan konsumen elektronik (e-consumers) sangat rendah. Kurang-lebih $56 \%$ (lima puluh enam persen) dari konsumen elektronik yang disurvai memberi alasan bahwa perusahaan/pengusaha asing tingkat kepatuhannya rendah terhadap hukum perlindungan konsumen. Sekitar $71 \%$ (tujuh puluh satu persen) konsumen yang disurvai menyatakan sangat sulit dalam penyelesaian sengketa, seperti kemungkinan muncul dari pengembalian barang (return of goods), penyelesaian harga (price settlement), jaminan (warranties), dan sebagainya sebagai alasan ketiadaan kepercayaan. Sekitar 65 $\%$ (enam puluh lima persen) konsumen yang disurvai yakin bahwa akan problematis apabila mereka mengubah pikiran dan mengembalikan produk yang mereka beli secara online dari penjual yang berada di luar negeri. ${ }^{9}$ Kondisi ini menunjukkan bahwa kepercayaan konsumen menjadi krusial, yang secara langsung menandai tuntutan pada para pengusaha untuk menciptakan perdagangan secara elektronik yang menumbuhkan kepercayan kepada konsumen.

Konsumen yang tidak mengetahui hak-haknya, pada kondisi tertentu melahirkan konsekuensi yang merugikannya, lebih-lebih tidak mengetahui adanya jaminan perlindungan yang diberikan oleh UU Perlindungan Konsumen. Tanpa mengetahui UU Perlindungan Konsumen, UU ITE, dan membaca secara detail informasi syarat kontrak, serta substansi kontrak yang disepakatinya, tidak hanya melahirkan kesulitan untuk meningkatkan kepercayaan konsumen pada transaksi online, namun juga langkah dan upaya hukum bagi konsumen yang niscaya dilakukan ketika terjadi iklan yang menyesatkan (misleading advertising) atau pelanggaran terhadap kontrak.

\section{Lemahnya Perlindungan Hukum}

Dalam hubungan dengan jaminan perlindungan, tidak sedikit konsumen yang tidak mengetahui adanya UU ITE atau jaminan perlindungan yang diberikan oleh peraturan perundangundangan lain, termasuk UU Perlindungan Konsumen. Lebih-lebih bagi konsumen yang tidak terbiasa dan belum berpengalaman dalam transaksi online dengan kekhawatiran transaksinya tidak sesuai dengan yang diharapkan. Kekhawatiran itu terutama pada penjual atau pelaku usaha yang menawarkan barangnya melalui toko online atau penyelenggara sistem elektronik yang fasilitasi transaksi tanpa sertifikasi.

Apabila dibandingkan dengan transaksi dalam dunia nyata, transaksi atau hubungan jual-beli dalam dunia maya ini memiliki potensi kejahatan atau setidak-tidaknya merugikan pihak lain, yang jauh lebih besar, di samping keuntungan masing-masing pihak. Hal itu disebabkan oleh lebih mudahnya interaksi antar pelaku usaha maupun dengan konsumen yang melampaui batas-batas negara bangsa. Meskipun di berbagai negara, bahkan secara internasional telah dibentuk berbagai peraturan yang berusaha untuk

$9 \quad$ Ibid., Hal.22-23. 
mengeliminasi tindakan-tindakan dalam transaksi yang merugikan pihak lain, namun hal tersebut tidak sepenuhnya dapat dikontrol oleh agen-agen negara yang memiliki otoritas untuk itu. Kesulitan mengontrol secara hukum terutama disebabkan oleh persoalan yurisdiksi maupun substansi hukum yang belum sepenuhnya harmonis antara satu negara dengan negara lainnya, termasuk mekanisme atau prosedur penyelesaian sengketa.

Kesenjangan posisi antara perusahan satu dan pelaku usaha lain atau antara pelaku usaha dan konsumen yang melakukan transaksi tidak mudah disejajarkan, dengan posisi konsumen lebih lemah dibanding pelaku usaha. Hal ini tampak menjadi sifat bawaan yang melekat pada prinsip kebebasan berkontrak. Oleh karena itu, tidak jarang muncul kontrak, yang secara substantif, keseluruhan dari maksudnya, baik dimengerti atau tidak dimengerti oleh konsumen, menempatkan konsumen pada posisi yang dirugikan. Tidak berlebihan apabila UU Perlindungan Konsumen membuat batasan-batasan bagi pelaku usaha. Batasan-batasan tersebut dapat berarti memberi kekuatan tambahan bagi konsumen sehingga posisinya yang lemah dapat dilindungi dari penyalahgunaan posisi kuat pelaku usaha untuk memeroleh keuntungan dengan merugikan konsumen. Dalam konteks perdagangan secara elektronik, UU ITE tidak memberi batasan bagi pelaku usaha atau pelaku usaha dalam hubungan dengan konsumen, sehingga sepenuhnya disandarkan pada UU Perlindungan Konsumen. Pengaturan UU ITE bersifat umum dalam hubungannya dengan penyelenggaraan transaksi elektronik dan sistem elektronik.

Batasan-batasan yang diatur UU Perlindungan Konsumen dalam hubungan dengan kontrak elektronik dan hal-hal yang berhubungan dengan kontrak elektronik tidak dengan sendirinya menjamin ketiadaan potensi kerugian konsumen disebabkan oleh syarat kontrak dan kontrak yang dibuat oleh perusahaan atau pelaku usaha. Hal ini menunjukkan bahwa syarat sah nya perjanjian pada pasal 1320 KUHPer belum berlaku efektif dikarenakan informasi syarat kontrak belum lengkap dan jelas di mana unsur cakap belum di aturan padahal seseorang dapat mengadakan transaksi jual beli pada usia 18 tahun ke atas, unsur sepakat masih banyak konsumen yang dirugikan karena dibuatnya kontrak standar atau baku dalam perdagangan secara elektronik menempatkan konsumen pada posisi yang lebih lemah dibandingkan dengan pelaku usaha, untuk unsur hal tertentu konsumen banyak dirugikan karena barang pesanan yang diterima oleh konsumen tidak sesuai dengan yang ditawarkan dan unsur sebab yang halal banyak barang terlarang dengan mudah didapat melalui perdagangan secara elektronik.

Terlepas dari pengetahuan konsumen terhadap ketentuan UU ITE, sebenarnya dalam UU ITE tersebut terdapat beberapa ketentuan yang secara tidak langsung memberikan perlindungan bagi konsumen. Ketentuan dimaksud di antaranya mengenai : informasi elektronik sebagai alat bukti hukum yang sah (Pasal 5), sertifikat digital (digital certificate), yang dalam Pasal 13 dan 14 UU ITE disebut "sertifikat elektronik", kewajiban menelenggarakan sistem elektronik secara andal dan aman serta bertanggung jawab (Pasal 15 dan 16 UU ITE). Kenyataannya hal tersebut sulit ditegakkan, sehingga terbuka kemungkinan muncul penyelenggara sistem elektronik yang belum tersertifikasi. 
Di samping UU ITE, di Indonesia telah dibentuk Peraturan Pemerintah Republik Indonesia Nomor 82 Tahun 2012 tentang Penyelenggaraan Sistem dan Transaksi Elektronik (selanjutnya disebut PP PSTE). Bagaimanapun juga keberadaan PP PSTE sebagai peraturan pelaksanaan dari UU ITE dari satu sisi merupakan jaminan perlindungan bagi konsumen dalam perdagangan secara elektronik, sekaligus menjelaskan rezim perdagangan secara elektronik di Indonesia yang berusaha membentuk peraturan yang memiliki legitimasi. Beberapa ketentuan yang memberi jaminan perlindungan itu diatur dalam Pasal 41- 45 dan PP PSTE, yaitu :

\section{B. Kelemahan Informasi Syarat Kontrak berakibat keadilan belum berpihak pada konsumen}

Informasi syarat kontrak dalam perdagangan elektronik, dari sudut pandang konsumen, seharusnya menentukan atau memengaruhi keputusan konsumen untuk melanjutkan sampai penutupan kontrak atau meninggalkan untuk tidak menutup kontrak. Kendati batasan-batasan mengenai kontrak dalam B2C telah ditentukan oleh UU Perlindungan Konsumen, UU ITE, dan PP PSTE, namun masih menyisakan permasalahan dalam praktik perdagangan secara elektronik, yaitu tidak sepenuhnya dapat menjamin perlindungan konsumen. Pasal 49 PP PSTE menentukan bahwa :

(1) Pelaku usaha yang menawarkan produk melalui Sistem Elektronik wajib menyediakan informasi yang lengkap dan benar berkaitan dengan syarat kontrak, produsen, dan produk yang ditawarkan.

(2) Pelaku Usaha wajib memberikan kejelasan informasi tentang penawaran, kontrak atau iklan.

(3) Pelaku Usaha wajib memberikan batas waktu kepada konsumen untuk mengembalikan barang yang dikirim apabila tidak sesuai dengan perjanjian atau terdapat cacat tersembunyi.

(4) Pelaku Usaha wajib menyampaikan informasi mengenai barang yang telah diirim.

(5) Pelaku Usaha tidak dapat membebani konsumen mengenai kewajiban membayar barang yang dikirim tanpa dasar kontrak.

Ketentuan tersebut hanya mengatur sehubungan dengan informasi syarat kontrak, yaitu "menyediakan informasi yang lengkap dan benar", sedangkan terhadap kontrak mengenai "memberikan kejelasan informasi". Ternyata atas pelanggaran atau tidak dipenuhinya kewajiban terhadap penyediaan informasi yang lengkap dan benar ini, PP PSTE tidak memberikan sanksi apapun, termasuk tidak mengancam dengan pengenaan sanksi administratif sebagaimana diatur oleh Pasal 84 PP PSTE. Pasal 84 PP PSTE menegaskan bahwa :

(1) Pelanggaran terhadap Pasal 7 ayat (1), Pasal 8 ayat (1) dan ayat (3), Pasal 12 ayat (1) dan ayat (2), Pasal 13, Pasal 14 ayat (1), Pasal 15 ayat (1), Pasal 16 ayat (1), Pasal 17 ayat (1), Pasal 18 ayat (1), Pasal 21, Pasal 22 ayat (1), Pasal 27, Pasal 29, Pasal 30 ayat (1), Pasal 37 ayat (1), Pasal 39 ayat (1), Pasal 58 ayat (1) dan ayat (2), Pasal 59 ayat (1), dan Pasal 78 ayat (1) dikenai sanksi administratif.

(2) Sanksi administratif sebagaimana dimaksud pada ayat (1) dapat berupa:

a. teguran tertulis;

b. denda administratif;

c. penghentian sementara; dan/atau

d. dikeluarkan dari daftar sbagaimana dimaksud dalam Pasal 5 ayat (4), Pasa 37 ayat (2), Pasal 62 ayat (1), dan Pasal 65 ayat (4). 
(3) Sanksi administratif diberikan oeh Menteri atau pimpinan Instansi Pengawas dan Pengatur Sektor terkait sesuai dengan ketentuan peraturan perundang-undangan.

(4) Pengenaan sanksi oleh pimpinan Instansi Pengawas dan Pengatur Sektor terkait sebagaimana dimaksud pada ayat (3) dilakukan setelah berkoordinasi dengan Menteri.

(5) Pengenaan sanksi admiinistratif sebagaimana dimaksud pada ayat (2) dan ayat (3) tidak menghapuskan tanggung jawab pidana dan perdata.

Tidak dikenakannya sanksi administratif atas pelanggaran Pasal 49 ayat (1) PP PSTE menunjukkan kebijakan bahwa informasi yang tidak lengkap dan benar merupakan persoalan pidana atau perdata, sehingga tidak menggunakan ketentuan UU ITE dan PP PSTE, namun hukum pidana atau perdata umum. Dengan kata lain, pelanggaran Pasal 49 ayat (1) PP PSTE merupakan cyber crime atau wanprestasi atau perbuatan melawan hukum perdata. Hal ini tentu sangat bergantung pada sikap aktif konsumen sebagai pihak yang dirugikan dalam transaksi elektronik untuk menggugat ataupun memperkarakan secara pidana, setidaktidaknya komplain pada pelaku usaha.

Beberapa kelemahan informasi syarat kontrak yang potensial menimbulkan posisi lemah bagi konsumen dapat dikemukakan sebagai berikut :

\section{Informasi Syarat Kontrak Mengarahkan pada Kontrak Baku yang Tidak Seimbang}

Telah menjadi gambar umum bahwa kontrak dalam perdagangan secara elektronik dibuat dalam bentuk baku atau standar (standard contract). Kontrak baku atau standar ini telah

10 Abdulhadi M. Alghandi, Abdul M. Alghamdi, 2011, The Law of E-Commerce, tampak dalam informasi syarat kontrak, meskipun secara implisit. Hal ini menunjukkan salah satu kesulitan untuk membuat cocok degan hukum kontrak (Indonesia) disebabkan ketika para pihak yang berkontrak, setidak-tidaknya salah satu di antara mereka, mengunakan komputer sebagai agen (a computer as an agent). $\mathrm{Di}$ dalam lingkungan elektronik, suatu e-mail dapat dikrim atau dijawab oleh komputer. Sebagai suatu kontrak hanya valid ketika terdapat suatu kehendak atau maksud untuk mengadakan hubungan hukum (legal relations), sedangkan kontrak melalui internet memungkinkan untuk dilakukan hanya satu orang, biasanya pembeli (buyer). Situs-situs perdagangan secara elektronik berbasis jaringan internet (web-base electronic commerce sites) sebagian besar menggunakan agen elektronik (electronic agent). Situs jaringan interaktif memungkinkan pengguna untuk mengirim informasi secara langsung dengan mengisi form elektronik. ${ }^{10}$ Agen elektronik ini juga yang mewakili untuk menyatakan konsumen dianggap sudah membaca informasi syarat kontrak dan memahaminya. Agen elektronik tidak lebih dari program komputer yang disusun terlebih dahulu (preprogrammed computer program) untuk menemukan informasi, membuat kontrak, serta interaksi lain dengan komputer pihak lain tanpa intervensi manusia. Secara keseluruhan membuat penawaran (offer) dan penerimaan (acceptance) dapat dilakukan sematamata secara otomatis. ${ }^{11}$

Kontrak baku pada toko online yang memfasilitasi pelaku usaha dan konsumen, lazimnya membatasi keduanya - pelaku usaha dan konsumen. Kontak baku tidak selalu dibuat oleh

E-Contract, E-Business, Bloomington: AuthorHouse, 2011. Hal.129.

11 Ibid., Hal.128. 
pelaku usaha karena pada toko online yang bukan diadakan oleh pelaku usaha, kontrak baku lazimnya dibuat oleh penyelenggara sistem perdagangan secara elektronik itu. Seperti Bukalapak.com, membuat informasi syarat kontrak yang ditujukan di satu sisi untuk pembeli (konsumen) dan pelapak (pelaku usaha), sekaligus menunjukkan kontrak baku dan informasi syarat kontrak baku itu dibuat oleh toko online, bukan pelaku usaha maupun konsumen. Hal tersebut disebabkan bukalapak.com berposisi sebagai perantara antara pelapak (pelaku usaha) dan pembeli (konsumen). Bukalapak.com memiliki kewenangan untuk melakukan tindakan yang dianggap perlu apabila terjadi penyalahgunaan dan/atau pelanggaran terhadap “Aturan Penggunaan". Bahkan Bukalapak.com memberi informasi mengenai posisinya dalam fasilitasi, bukan hanya informasi syarat kontrak yang mengandung klausula bagi pelaku usaha dan konsumen. Umumnya, informasi syarat kontrak yang bersifat umum pada "Aturan Penggunaan" mengandung substansi kewenangan dan hak Bukalapak sebagai penyedia layanan online atas transaksi antara pelaku usaha dan konsumen. Berbeda halnya dengan Amazon.com yang merupakan toko online sekaligus pelaku usaha, sehingga kontrak baku dan informasi syarat kontrak dibuat oleh amazon.com dalam posisi yang berhadapan dengan konsumen. Meskipun demikian, isu soal keadilan di antara dua jenis toko yang berbeda posisi itu sama. Artinya, bisa berlaku adil di satu sisi dan tidak adil di sisi lain dalam menentukan klausulaklausula kontrak dan memberikan informasi mengenai syarat kontrak.

Permasalahan kontrak baku dalam informasi syarat kontrak bukan terletak pada pembentukan klausula-klausula yang bersifat sepihak oleh toko online, sementara pihak lain (konsumen) hanya menyepakati atau meninggalkan toko online, namun pada keseimbangan perlindungan kepentingan pihak-pihak yang bertransaksi. Ketidakseimbangan perlindungan kepentingan potensial merugikan salah satu pihak, khususnya konsumen. Dalam hubungan dengan keadilan, ketidakseimbangan perlindungan kepentingan dalam kontrak baku itu menjelaskan ketidakadilan.

Kenyataan menunjukkan bahwa tidak ada toko online yang menawarkan dalam informasi syarat kontrak mengenai kemungkinan konsumen melakukan negosiasi atas klausulaklausula kontrak perdagangan. Informasi syarat kontrak menunjukkan "pendekatan berdasarkan kekuasaan pada kontrak" (power-based approaches to contact). Kekuasaan dimaksud adalah pelaku usaha atau toko online yang membuat informasi itu..

\section{Informasi Syarat Kontrak Sulit Diakses}

Terdapat dua persoalan mengenai asumsi pengguna, pelaku usaha, bahkan penyelenggara fasilitas toko online yang menunjukan bahwa informasi syarat kontrak merupakan komponen perdagangan secara elektronik yang dapat diabaikan untuk diketahui di samping tidak harus sangat terinci. Asumsi bahwa informasi syarat kontrak bukan ihwal yang penting untuk diketahui pada permulaan dapat dijelaskan berdasarkan sulitnya mengakses mengenai informasi syarat kontrak. Hal ini disebabkan penyelenggara sistem elektronik untuk perdagangan secara elektronik tidak menempatkan informasi syarat kontrak itu pada awal setiap kali seseorang hendak membeli barang atau memanfaatkan layanan toko online. Untuk mengetahui syarat kontrak, konsumen niscaya mencari dari berbagai menu yang tidak selalu mudah diketahui. 
Seperti dialami oleh pembeli yang saya wawancarai pada toko online Lazada (lazada.co.id), informasi syarat kontrak (informasi mengenai syarat dan ketentuan) ditempatkan dalam menu atau platform/layanan "kebijakan". 12 Informasi syarat kontrak yang sulit diakses, maka terhadap perubahan syarat dan ketentuan yang dilakukan oleh toko online dengan demikian juga sulit diketahui. Informasi, pemberitahuan atau publikasi adanya perubahan syarat dan ketentuan masih problematis bagi konsumen karena tidak disebutkan secara spesifik. Sebagai contoh informasi syarat kontrak mengenai perubahan substansi yang dilakukan

Sebagaicontoh, pada toko online Bukalapak untuk mengetahui informasi syarat kontrak, Pembeli yang saya wawancarai harus melalui beberapa tahap membuka "menu", yaitu "profil", kemudian "menu lain", "informasi", dan "aturan pengunaan". Mengenai perubahan ditentukan pada bagian "informasi umum" bahwa :

Aturan Penggunaan Bukalapak dapat berubah sewaktu-waktu dan/atau diperbaharuidari waktu ke waktu tanpa pemberitahuan terlebih dahulu. Dengan mengakses Bukalapak, Pengguna dianggap menyetujui perubahanperubahan dalam Aturan Penggunaan Bukalapak. $^{13}$

Aturan Penggunaan Bukalapak pada Situs Bukalapak berlaku mutatis mutandis untuk penggunaan Apliasi Bukalapak.

Berbeda dengan salah satu Pembeli Tokopedia yang saya wawancarai, dalam bagian "Syarat dan Ketentuan", khususnya pada huruf V mengenai "Pembaharuan", ditegaskan bahwa :

12 Wawancara dengan Evi pada tanggal 3 Juni 2020 , pukul 10.00 WIB

13 Wawancara dengan Risqi pada tanggal $2 \mathrm{Mei}$ 2020, pukul 14.00 WIB
Syarat \& ketentuan mungkin diubah dan/atau diperbaharui dari waktu ke waktu tanpa pemberitahuan sebelumnya. Tokopedia menyarankan agar anda membaca secara seksama dan memeriksa halaman Syarat \& Ketentuan ini dari waktu ke waktu untuk mengetahui perubahan apapun. Dengan tetap mengakses dan menggunakan layanan Tokopedia, maka pengguna dianggap menyetujui perubahanperubahan dalam Syarat \& Ketentuan. ${ }^{14}$

Konten ini niscaya diakses pada awal seseorang mendaftar sebagai pengguna dan sebagaimana dikatakan di atas, setelah pengguna terdaftar, maka perubahan dianggap diketahui dan disetujui oleh pengguna kendati pengguna tidak mengakses Syarat dan Ketentuan yang berubah tersebut pada setiap waktu memasuki toko online tersebut.

\section{Informasi syarat kontrak tidak lengkap dan jelas}

Di samping persoalan akses pada syarat kontrak yang menuntut keaktivan pengguna, informasi syarat kontrak yang tidak lengkap akan menyebabkan potensi ketidakamanan perdagangan secara elektronik. Ketidaklengkapan informasi syarat kontrak berbanding lurus dengan ketidakjelasan syarat kontrak. Hal ini dapat dilakukan dengan sengaja atau semata-mata ketidakmampuan dalam menyusun informasi mengenai syarat-syarat kontrak. Lengkapnya informasi syarat kontrak tentu membawa pada sikap kehati-hatian pembeli atau pelaku usaha maupun penyelenggara sistem elektronik, demikian juga sebaliknya. Betapa tidak! Ketidaklengkapan informasi syarat kontrak membuka ruang adanya informasi palsu dari pihak

14 Wawancara dengan Ridwan pada tanggal 30 April 2020, pukuol 14.00 WIB 
lain demi keuntungan pribadi. Hal tersebut disebabkan ketidaklengkapan informasi syarat kontrak menjadikan konsumen, bahkan pelaku usaha itu sendiri tidak mampu mengenali penawaran, penerimaan, atau transaksi yang terjadi itu benar adanya atau palsu. Informasi syarat kontrak merupakan bagian dari keamanan perdagangan secara elektronik. Artinya, semakin minimal informasi syarat kontrak, maka semakin tidak aman transaksi elektronik yang dibuat oleh para pihak. Sebaliknya, semakin lengkap informasi syarat kontrak, maka perdagangan secara elektronik tersebut lebih aman. Informasi syarat kontrak yang lengkap sangat penting, terutama bagi lingkungan konsumen yang belum terbiasa berbelanja secara online. Informasi syarat kontrak yang lengkap setidak-tidaknya memberi pengetahuan pada konsumen atas kesepakatankesepakatan yang dibuat dengan pelaku usaha maupun penyelenggara sistem layanan perdagangan secara elektronik.

Penyelenggara sistem elektronik yang memfasilitasi perdagangan secara elektronik di antaranya masih sebatas memenuhi secara formal ketentuan Pasal 48 ayat (3) huruf e PP PSTE, yaitu kontrak elektronik paling sedikit memuat prosedur dalam hal terdapat pembatalan oleh para pihak. Kenyataannya informasi syarat kontrak mengenai prosedur tersebut tidak terurai dengan jelas seperti yang di alami oleh salah satu Pembeli yang saya wawancarai ${ }^{15}$ pada waktu berbelanja di Bukalapak diinformasikan dalam bentuk pertanyaan, seperti mengenai "bagaimana cara mengajukan komplain pengembalian barang, jika transaksi sudah selesai (remit)?" maupun pernyataan. Informasi syarat kontrak

15 Wawancara dengan Keyza pada tanggal 5 Juni 2020, pukul 19.00 WIB mengenai retur ini menyebutkan bahwa (pada bagian "Transaksi"):

Langkah-langkah melakukan retur bisa dibaca pada halaman ini : Ketika transaksimu sudah selesai (remit), uang pembayaranmu telah kami teruskan ke pelapak. Terhadap transaksi tersebut, komplain pengembalian barang (retur) tidak bisa lagi dilakukan. Jika kamu masih ingin memproses pengembalian barang (retur) di luar sistem Bukalapak, kami tidak akan membantu pengawasan maupun bertanggung jawab terhadap proses tersebut.

Bukalapak akan menahan dana hingga ada kesepakatan (antara Pembeli dan Pelapak) apakah akan dilakukan pengembalian barang ke Pelapak atau tidak.

Bukalapak akan mengembalikan dana transaksi ke Pembeli jika dalam waktu $5 \times 24$ jam Pelapak tidak merespon pesan permintaan retur dari Pembeli di halaman detail transaksi. Selanjutnya, Pembeli wajib mengirimkan barang tersebut ke kantor Bukalapak.

Informasi syarat kontrak yang tidak lengkap dan jelas merupakan bentuk ketidakadilan pada konsumen sebagai pihak yang memiliki posisi lebih lemah dibanding pelaku usaha. Oleh karena itu, tidak sejalan dengan rinsip The Privity of Contract. dan penegakannya sangat tidak disetujui ketika satu pihak mempertukarkan sehingga menyebabkan pihak lain menjadi salah informasi).

Kesalahan penerimaan informasi disebabkan informasi syarat kontrak cacat, baik karena pelaku usaha tidak jujur atau informasi itu tidak lengkap merupakan faktor yang niscaya menjadikan kontrak tidak sah (valid). Ketiadaan ketentuan mengenai hal ini sangat merugikan konsumen atau setidak-tidaknya kepentingan konsumen 
tidak terlindungi. Sehingga keadilan belum berpihak pada konsumen.

\section{Kesimpulan}

Informasi syarat kontrak dalam perdagangan secara elektronik masih menempatkan konsumen pada posisi yang lemah meskipun telah terdapat UU ITE. Ketentuan-ketentuan dalam UU ITE maupun UU Perlindungan Konsumen masih sangat sederhana untuk mengatakan telah adanya jaminan keadilan dalam perdagangan elektronik khususnya bagi konsumen, bahkan UU ITE belum mengatur mengenai validitas kontrak sebagai bagian dari informasi syarat kontrak. Kelemahan perlindungan konsumen yang menunjukkan keadilan belum berpihak kepada konsumen diantaranya adalah : (a) UU ITE ataupun UU Perlindungan Konsumen dan informasi syarat kontrak memungkinkan bahkan mengarah pada kontrak baku yang tidak seimbang, (b) Informasi syarat kontrak sulit diakses, (c) Informasi syarat kontrak tidak lengkap dan jelas.

\section{Saran}

1. Pemerintah dan DPR perlumemperbaikipasal 9 UU No.11 Tahun 2008

2. Pemerintah segera mengeluarkan peraturan pemerintah tentang pembentukan Lembaga sertfikasi untuk melindungi konsumen yang diwajibkan bagi pelaku usaha yang menyelenggarakan transaksi elektronik.

\section{Daftar Pustaka}

Buku - Buku

Abdul M. Alghamdi, 2011, The Law of E-Commerce, E-Contract, EBusiness, Bloomington: AuthorHouse

Faye Fangfei Wang, 2014, Law of Electronic Commercial
Transactions Contrmporary Issues in The EU, US and China, London and New York: Routledge

Sutatip Yuthayotin, 2015, Access to Justice in Transnational B2c ECommerce A Multidimentional Analysis of Consumer Protection Mechanisms, Switzerland: Springer

\section{Perundang-Undangan}

UU Nomor 8 tahun 1999 tentang Perlindungan Konsumen

UU Nomor tahun 2008 tentang Informasi dan Transaksi Elektronik

\section{Internet}

www. artikata.com, atau https://www.kamusbesar.com/kes adaran, diunduh pada Jum'at, 16 April 2020, pukul 09.57 WIB.

Thompson S.H. Teo, Jing Liu, 2007, "Consumer trust in e-commerce in the Journal of Management Science, h.22 (22-38), www.elsevier.com/locate/omega atau www.sciencedirect.com, diakses pada tanggal 25 Maret 2020, pukul 10.00 WIB 